\title{
FAKTOR-FAKTOR YANG BERHUBUNGAN DENGAN KEJADIAN ANEMIA PADA IBU HAMIL DI PUSKESMAS MAKRAYU PALEMBANG
}

\author{
*Annisa Khoiriah', Latifah² \\ ${ }^{1}$ Kebidanan/D III Kebidanan/Kebidanan, Sekolah tinggi ilmu kesehatan, ${ }^{*}$ Email: annisakhrsjy@gmail.com \\ ${ }^{2}$ Keperawatan/S1 Keperawatan/Keperawatan, Sekolah tinggi ilmu kesehatan, Email: latifahbilly41@gmail.com
}

INFO ARTIKEL
Riwayat Artikel:
Diterima: 14-09-2019
Disetujui: 27-07-2020

Kata Kunci:

Umur

Paritas

Pengetahuan

Kejadian Anemia

\begin{abstract}
Abstrak: : Anemia adalah suatu penyakit dimana kadar Hemoglobin $(\mathrm{Hb})$ dalam darah kurang dari normal. Anemia berbeda dengan tekanan darah rendah. Menurut hasil analisis Survey Demografi Indinesia (SDKI) 2012, penyebab utama kematian ibu secara langsung adalah perdarahan $28 \%$, eklampsia $24 \%$, dan infeksi $11 \%$. Penyebab tidak langsung adalah anemia 51\% (SDKI, 2012). Faktor yang dapat menimbulkan anemia, antara lain kurangnya asupan zat besi dan protein dari makanan, adanya gangguan absorpsi di usus, perdarahan akut maupun kronis, dan meningkatnya kebutuhan zat besi seperti pada wanita hamil, masa pertumbuhan dan masa penyembuhan dari penyakit. Penelitian ini bertujuan untuk mengetahui hubungan faktor-faktor yang berhubungan dengan kejadian anemia pada ibu hamil di Puskesmas Makrayu Palembang tahun 2019. Jenis penelitian ini menggunakan metode survei analitik dengan pendekatan cross sectional dengan jumlah populasi sebanyak 256 orang ibu hamil dengan jumlah sampel 38 orang ibu hamil yang dilakukan pada tahun 2019. Sampel yang di ambil menggunakan tehnik accidental sampling. Pengolahan data menggunakan data primer dengan distribusi frekuensi pada analisis univariat, dan uji chisquare pada analisis bivariat. Berdasarkan hasil uji statistik didapatkan ada hubungan yang bermakna antara umur $(p$ value $=0,023)$, paritas $(p$ value $=0,005)$, dan pengetahuan $(p$ value $=0,011$ ) dengan kejadian anemia pada ibu hamil di Puskesmas Makrayu Palembang tahun 2019. Disarankan pada institusi kesehatan agar meningkatkan lagi mutu pelayanan kesehatan khususnya untuk anemia pada kehamilan.
\end{abstract}

ABSTRAK

\begin{abstract}
Pregnancy is fertilization or the combination of spermatozoa and ovum that continued by implantation from fertilization to delivery period. The normal pregnancy period is 40 weeks or 10 months or 9 months based on international calendar. There were some factors could cause anemia such as the lack of ferrum and protein from the foods, intestine absorption problem, acute or chronicle bleeding, need of ferrum for expectant mothers, and recovery period. The purpose of this study was to identify the factors correlate with anemia to expectant mother at Makrayu public health center Palembang in 2014. The analytical survey through cross sectional method was used in this study. The population of the study was 256 expectant mothers and the total number of the sample was 38 expectant mothers on 2019. The accidental sampling method was used to select the sample. The primer data was used at univariate analysis and chi-square was used at bivariate analysis. The result of the study showed that there was a significant correlation between age ( $p$-value 0.023), parity ( $p$-value 0.005, knowledge ( $p$-value 0.011) and anemia to expectant mothers at Makrayu public health center Palembang in 2019. Finally, it is hoped that Health institution could improve service quality especially for anemia to expectant mother. It is hoped that next study could improve and ad some variables to get more information.
\end{abstract}

\section{A. LATAR BELAKANG}

Kehamilan adalah fertilisasi atau penyatuan dari spermatozoa dan ovum dan dilanjutkan dengan nidasi atau implantasi bila dihitung dari saat fertilisasi hingga lahirnya bayi, kehamilan normal akan berlangsung dalam waktu 40 minggu atau 10 bulan atau 9 bulan menurut kalender internasional[1].

World Health Organization (WHO) menyebutkan, $20 \%$ dari 515.00o kematian maternal diseluruh dunia di sebabkan oleh anemia, dan penderita lebih banyak di banding pria. Menurut laporan pembangunan 2007, tercatat angka kematian ibu di beberapa negara ASEAN (Assosiation South East Asia Nations) seperti di Vietnam 18 per 100.00o kelahiran hidup, di Malaysia 55 per 100.000 kelahiran hidup, Filiphina 26 per 100.00o kelahiran hidup dan Singapura 3 per 100.000 kelahiran hidup. Sedangkan di Indonesia mencapai 359 per 100.000 kelahiran hidup[2]. Menurut hasil analisis Survey Demografi Indinesia (SDKI) 2012, penyebab utama kematian ibu secara langsung adalah perdarahan $28 \%$, eklampsia $24 \%$, dan infeksi $11 \%$. Penyebab tidak langsung adalah anemia 51\% .[3]

Angka Kematian Ibu (AKI) dan Angka Kematian Bayi (AKB) di Indonesia menurut SurveI Demografi dan Kesehatan Indonesia (SDKI) tahun 2007 adalah 228/100.000 kelahiran hidup, dan AKB 34/1000 kelahiran hidup. Pada tahun 2012 AKI mengalami peningkatan menjadi 359/100.0oo kelahiran hidup dan AKB menurun menjadi 32/100o kelahiran hidup. Penyebab langsung kematian ibu sebesar 90\% terjadi saat persalinan dan segera setelah persalinan, angka ini 
masih jauh di atas target rata-rata untuk mewujudkan tujuan pembangunan Millenium Development Goals tahun 2015 yang menargetkan AKI di Indonesia menjadi 102/100.00o kelahiran hidup, sedangkan AKB 23/100o kelahiran hidup [4]. Faktor yang dapat menimbulkan anemia defisiensi besi, antara lain kurangnya asupan zat besi dan protein dari makanan, adanya gangguan absorpsi di usus, perdarahan akut maupun kronis, dan meningkatnya kebutuhan zat besi seperti pada wanita hamil, masa pertumbuhan dan masa penyembuhan dari penyakit[5]. Anemia pada ibu hamil tahun 2010 sebanyak 692 orang dari $45.652 \mathrm{ibu}$ hamil $(1,51 \%)$, tahun 2011 sebanyak 646 orang dari $36.487 \mathrm{ibu}$ hamil (1,77\%). Terjadi peningkatan prevalensi anemia gizi berdasarkan hasil pengukuran kadar Hb tahun 2012, sebanyak 675 orang dari 48.325 ibu hamil $(1,4 \%)$ [6].

Menurut data dari Dinas Kesehatan Kota Palembang angka kejadian anemia pada tahun 2011 yaitu sebanyak 1.455 ibu yang terkena anemia $(5,44 \%)$ dari 26.706 ibu hamil, sedangkan pada tahun 2012 Dari 39 Puskesmas terdapat 1 Puskesmas yang cakupan jumlah ibu hamil anemia melebihi 10\% Puskesmas Merdeka (10.6\%). Jika dilihat cakupan Tablet Tambah Darah ibu hamil di Kota Palembang tahun 2012 sebesar 96\% melebihi target kota Palembang dengan capaian tertinggi yaitu 100\% Puskesmas Sako dan terendah Puskesmas 23 Ilir yaitu 86\%, dan pada tahun 2013 yaitu sebanyak 966 (3\%) dari 32.205 ibu hamil[9]. Berdasarkan data yang diperoleh dari Puskesmas Makrayu Palembang tentang anemia pada ibu hamil menunjukkan adanya peningkatan 3 tahun terakhir, yaitu tahun 2011 terdapat 25 dari 2616 atau $0,25 \%$ ibu hamil dengan anemia, tahun 2012 terdapat 48 dari 1920 atau 2,5\% ibu hamil dengan anemia dan pada tahun 2013 terdapat 69 dari 1603 atau 4,17\% ibu hamil dengan anemia.[10]

Berdasarkan latar belakang yang telah diuraikan, bahwa anemia dapat menimbulkan angka kesakitan dan kematian, serta beresiko terjadinya berat badan lahir rendah (BBLR) dan dapat menyebabkan meningkatnya resiko berkembangnya masalah kesehatan, serta data yang di peroleh masih terjadi peningkatan kejadian anemia pada ibu hamil di Puskesmas Makrayu Palembang dan dikhawatirkan angka tersebut akan terus meningkat, dan sebelumnya di Puskesmas Makrayu Palembang dengan objek batasan penelitian tentang anemia dengan variabel umur, pengetahuan dan paritas.

\section{B. METODE PENELITIAN}

Penelitian ini menggunakan metode survey analitik dengan menggunakan pendekatan secara cros sectional dimana variabel independen (umur, paritas dan pengetahuan) dan variabel dependen (anemia pada ibu hamil), dengan jumlah populasi sebanyak 256 orang ibu hamil dengan jumlah sampel 38 orang ibu hamil yang dilakukan pada tahun 2019. Sampel yang di ambil menggunakan tehnik accidental sampling. Pengolahan data menggunakan data primer dengan distribusi frekuensi pada analisis univariat, dan uji chisquare pada analisis bivariate

\section{HASIL DAN PEMBAHASAN}

Hasil

\section{Analisis Univariat}

a. Karakteristik Responden

TABEL 1

Distribusi Responden Berdasarkan Umur, Paritas dan Pengetahuan Ibu di Puskesmas Makrayu Palembang

\begin{tabular}{|c|c|c|c|c|}
\hline No & \multicolumn{2}{|c|}{$\begin{array}{c}\text { Karakteristik } \\
\text { Responden }\end{array}$} & $\mathbf{N}$ & $\%$ \\
\hline \multirow[t]{3}{*}{1} & \multirow[b]{2}{*}{ Umur } & Resiko & 21 & 52,3 \\
\hline & & $\begin{array}{l}\text { Tidak } \\
\text { berisiko }\end{array}$ & 17 & 44,7 \\
\hline & \multicolumn{2}{|c|}{ Jumlah } & 38 & 100 \\
\hline \multirow[t]{3}{*}{2} & \multirow{2}{*}{ Paritas } & Tinggi & 16 & 42,1 \\
\hline & & Rendah & 22 & 57,9 \\
\hline & \multicolumn{2}{|c|}{ Jumlah } & 38 & 100 \\
\hline \multirow[t]{3}{*}{3} & \multirow[t]{2}{*}{ Pengetahuan } & $\begin{array}{c}\text { Kurang } \\
\text { baik }\end{array}$ & 23 & 60,5 \\
\hline & & Baik & 15 & 39,5 \\
\hline & \multicolumn{2}{|c|}{ Jumlah } & 36 & 100 \\
\hline
\end{tabular}

Berdasarkan tabel di atas didapat bahwa responden terbanyak menurut kelompok umur berada pada umur beresiko sebanyak 21 orang atau dengan persentase 52,3 \%. Responden terbanyak menurut paritas yaitu paritas rendah sebanyak 22 orang atau dengan persentase 57,9 \%. Responden terbanyak menurut pengetahuan yaitu pengetahuan kurang baik sebanyak 23 orang atau dengan persentase 60,5\%.

\section{b. Kejadian Anemia pada Ibu Hamil}

Kejadian anemia pada ibu hamil di kelompokkan menjadi 2, yaitu "anemia" (bila kadar $\mathrm{Hb}<11$ gr\%) dan "tidak anemia" (bila kadar $\mathrm{Hb} \geq 11 \mathrm{gr} \%$ ), untuk lebih jelasnya dapat di lihat pada tabel 5.1 sebagai berikut.

TABEL 2.

Distribusi Frekuensi Responden Menurut Kejadian Anemia pada Ibu Hamil di Puskesmas Makrayu Tahun 2019

\begin{tabular}{cccc}
\hline No & $\begin{array}{c}\text { Kejadian anemia } \\
\text { pada ibu hamil }\end{array}$ & Frekuensi & Persentase \\
\hline 1. & Ya & 13 & $34,2 \%$ \\
2. & Tidak & 25 & $65,8 \%$ \\
\hline & Jumlah & 38 & $100 \%$
\end{tabular}

Dari tabel diatas dapat dilihat bahwa dari 38 responden yang mengalami anemia sebanyak 13 orang $(34,2 \%)$, dan yang tidak mengalami anemia sebanyak 25 orang $(65,8 \%)$.

\section{Analisis Bivariat}

a. Hubungan Umur Ibu dengan Kejadian pada Ibu Hamil di Puskesmas Makrayu Palembang

Variabel umur ibu dikelompokan menjadi 2 kategori, yaitu resiko (jika umur ibu $<20$ atau $>35$ tahun), dan tidak beresiko (jika umur ibu $20-35$ tahun), yang dihubungkan dengan kejadian anemia pada ibu hamil, dengan menggunakan uji statistik chisquare. Untuk lebih jelas dapat dilihat pada tabel 5 berikut: 
TABEL 3.

Distribusi Hubungan Umur Ibu dengan Kejadian Anemia pada Ibu Hamil di Puskesmas Makrayu Palembang

\begin{tabular}{|c|c|c|c|c|c|c|c|c|}
\hline \multirow{3}{*}{$\begin{array}{r}\mathrm{N} \\
\mathrm{O}\end{array}$} & Umur & \multicolumn{4}{|c|}{$\begin{array}{l}\text { Kejadian anemia pada } \\
\text { ibu hamil }\end{array}$} & \multirow[b]{3}{*}{$\mathrm{N}$} & \multirow[b]{3}{*}{$\%$} & \multirow[t]{3}{*}{$\begin{array}{c}P \\
\text { value }\end{array}$} \\
\hline & & \multicolumn{2}{|c|}{$\mathrm{Ya}$} & \multicolumn{2}{|c|}{ Tidak } & & & \\
\hline & & $\mathrm{n}$ & $\%$ & $\mathrm{n}$ & $\%$ & & & \\
\hline 1. & Risiko & 11 & 52,4 & 10 & 47,6 & 21 & 100 & 0,02 \\
\hline 2. & $\begin{array}{l}\text { Tidak } \\
\text { Risiko }\end{array}$ & 2 & 11,8 & 15 & 88,2 & 17 & 100 & 3 \\
\hline
\end{tabular}

Berdasarkan hasil analisis hubungan antara umur ibu dengan kejadian anemia pada ibu hamil, diketahui bahwa dari 21 ibu hamil yang umurnya risiko yang mengalami anemia sebanyak 11 orang $(52,4 \%)$ dan yang tidak anemia sebanyak 10 orang (47,6\%), sedangkan dari 17 orang ibu hamil yang umurnya tidak risiko dan mengalami anemia sebanyak 2 orang (11,8\%), dan yang tidak anemia sebanyak 15 orang $(88,2 \%)$.

Hasil uji statistik menunjukan adanya hubungan yang bermakna antara umur dengan kejadian anemia pada ibu hamil yang di tunjukan dengan $P$ value $=$ 0,023, sehingga hipotesis yang menyatakan ada hubungan antara umur dengan kejadian anemia pada ibu hamil di Puskesmas Makrayu Palembang diterima.

b. Hubungan Paritas dengan Kejadian Anemia pada Ibu Hamil di Puskesmas Makrayu Palembang

Variabel paritas ibu dikelompokan dalam 2 kategori yaitu "tinggi" bila jumlah anak > 3 orang, dan "rendah" bila jumlah anak $\leq 3$ orang, yang dihubungkan dengan kejadian anemia pada ibu hamil, dengan menggunakan uji statistik Chi - square. Untuk lebih jelas dapat dilihat pada tabel 6 berikut:

TABEL 4.

Distribusi Hubungan Paritas dengan Kejadian Anemia pada Ibu Hamil di Puskesmas Makrayu Palembang

\begin{tabular}{|c|c|c|c|c|c|c|c|c|}
\hline \multirow{3}{*}{$\begin{array}{l}\mathrm{N} \\
\mathrm{O}\end{array}$} & Paritas & \multicolumn{4}{|c|}{$\begin{array}{c}\text { Kejadian anemia pada } \\
\text { ibu hamil }\end{array}$} & & & \multirow{2}{*}{$\begin{array}{c}P \\
\text { valu } \\
e\end{array}$} \\
\hline & & \multicolumn{2}{|c|}{$\mathrm{Ya}$} & \multicolumn{2}{|c|}{ Tidak } & & & \\
\hline & & $\mathrm{n}$ & $\%$ & $\mathrm{n}$ & $\%$ & $\mathrm{~N}$ & $\%$ & \\
\hline 1. & Tinggi & 10 & 62,5 & 6 & 37,5 & 16 & 100 & 0,00 \\
\hline 2. & Rendah & 3 & 13,6 & 19 & 86,4 & 22 & 100 & \\
\hline
\end{tabular}

Dari tabel diatas dapat dilihat bahwa responden yang paritasnya tinggi sebanyak 16 orang dan yang mengalami anemia yaitu 10 orang $(62,5 \%)$, yang tidak anemia sebanyak 6 orang (37,5\%). Sedangkan ibu hamil yang paritasnya rendah berjumlah 22 orang, 3 orang (13,6\%) diantaranya mengalami anemia, dan 19 $(86,4 \%)$ orang tidak mengalami anemia. Hasil uji statistik menunjukan adanya hubungan yang bermakna antara paritas dengan kejadian anemia pada ibu hamil yang di tunjukan dengan $P$ value $=$ o,005, sehingga hipotesis yang menyatakan ada hubungan antara paritas dengan kejadian anemia pada ibu hamil di Puskesmas Makrayu Palembang.

c. Hubungan Pengetahuan dengan Kejadian Anemia pada Ibu Hamil di Puskesmas Makrayu Palembang
TABEL 5.

Distribusi Hubungan Pengetahuan dengan Kejadian Anemia pada Ibu Hamil di Puskesmas Makrayu Palembang

\begin{tabular}{|c|c|c|c|c|c|c|c|c|}
\hline $\mathrm{N}$ & Pengeta & \multicolumn{4}{|c|}{$\begin{array}{l}\text { Kejadian anemia pada } \\
\text { ibu hamil }\end{array}$} & & & \multirow{2}{*}{$\begin{array}{l}P \\
\text { val } \\
\text { ue }\end{array}$} \\
\hline \multirow{2}{*}{$\begin{array}{l}1 \\
0\end{array}$} & huan & & $\mathrm{a}$ & & & & & \\
\hline & & $\mathrm{n}$ & $\%$ & $\mathrm{n}$ & $\%$ & $\mathrm{~N}$ & $\%$ & \multirow{2}{*}{$\begin{array}{c}0,0 \\
11\end{array}$} \\
\hline 1. & $\begin{array}{l}\text { Kurang } \\
\text { baik }\end{array}$ & 12 & 52,2 & 11 & 47,8 & 23 & 100 & \\
\hline 2. & Baik & 1 & 6,7 & 14 & 93,3 & 15 & 100 & \\
\hline
\end{tabular}

Dari tabel diatas dapat dilihat bahwa responden yang mempunyai pengetahuan kurang baik sebanyak 23 orang, yang menderita anemia sebanyak 12 orang (52,2\%), dan yang tidak mengalami anemia yaitu sebanyak 11 orang (47,8\%). Sedangkan ibu hamil yang pengetahuannya baik sebnyak 15 orang, 1 orang $(6,7 \%)$ diantaranya mengalami anemia, dan yang tidak anemia sebanyak 14 orang (93,3\%). Hasil uji statistik menunjukkan adanya hubungan yang bermakna antara pengetahuan dengan kejadian anemia pada ibu hamil yang di tunjukan dengan $P$ value $=0,011$, sehingga hipotesis yang menyatakan ada hubungan antara pengetahuan dengan kejadian anemia pada ibu hamil di Puskesmas Makrayu Palembang.

\section{Pembahasan}

\section{a. Hubungan Antara Umur Ibu dengan Kejadian Anemia di Puskesmas Makrayu Palembang}

Berdasarkan hasil analisis univariat menunjukkan bahwa dari 38 responden diketahui 21 orang (55,3\%) termasuk dalam umur dengan risiko, dan ibu hamil yang umurnya tidak risiko yaitu berjumlah 17 orang (44,7\%). Sedangkan dari hasil analisis bivariat diketahui bahwa ibu hamil yang umurnya beresiko dan mengalami anemia sebanyak 11 orang $(52,4 \%)$, dan yang tidak mengalami anemia sebanyak 10 orang (17,9\%). Sedangkan ibu hamil yang umurnya tidak resiko dan mengalami anemia sebanyak 2 orang $(11,8 \%)$, dan yang tidak anemia sebanyak 15 oramg $(88,2 \%)$. Berdasarkan hasil uji chi-square diperoleh $\mathrm{P}$ value $=0,023<\alpha=0,05$. Dapat disimpulkan bahwa ada hubungan yang bermakna antara umur ibu dengan kejadian anemia.

Hasil penelitian ini sejalan dengan penelitian yang dilakukan oleh Serli pada tahun 2010 di Palembang dengan jumlah sampel 150 responden, dengan kelompok umur risiko tinggi dan anemia 28 orang (50,0\%), yang tidak anemia sebanyak 28 orang (100\%). Sedangkan pada umur risiko rendah dan anemia sebesar 21 orang $(22,3 \%)$, dan tidak anemia 73 orang (77,7\%), diperoleh $p$ value $=0,000<\alpha=0,05$.

Secara teori umur $<20$ tahun secara biologis mentalnya belum optimal dengan emosi yang cenderung labil, mental yang belum matang sehingga mudah mengalami keguncangan yang mengakibatkan kurangnya perhatian terhadap pemenuhan kebutuhan zat gizi terkait dengan penurunan daya tahan tubuh. Berbagai faktor yang saling berpengaruh dan tidak 
menutup kemungkinan usia yang matang sekalipun untuk hamil angka kejadian anemia jauh lenih tinggi. [7]. Berdasarkan hasil penelitian, teori, serta hasil penelitian terkait maka peneliti berpendapat bahwa umur ibu hamil yang $<20$ tahun dan $>35$ tahun sangat beresiko terjadi anemia dalam kehamilan di banding dengan ibu hamil yang berumur 20-35 tahun. Karena umur wanita yang $<20$ tahun pada usia ini belum siap untuk hamil, baik secara fisik maupun psikologis, sehingga mempengaruhi asupan gizi dan alat reproduksi secara umum. Sedangkan pada umur ibu > 35 tahun pada usia ini fungsi organ reproduksi juga sudah mengalami penurunan sehingga tidak dapat bekerja secara maksimal, oleh karena itu rentan untuk terjadinya komplikasi-komplikasi salah satunya anemia dalam kehamilan.

\section{b. Hubungan Antara Paritas Ibu dengan Kejadian Anemia di Puskesmas Makrayu Palembang}

Berdasarkan hasil analisis univariat menunjukan bahwa dari 38 responden didapatkan 16 responden $(65,8 \%)$ mempunyai paritas tinggi dan 22 orang $(34,2 \%)$ dengan paritas rendah. Sedangkan hasil analisis bivariat diketahui bahwa ibu hamil yang paritasnya tinggi dan anemia sebanyak 10 orang $(62,5 \%)$, dan yang tidak anemia sebanyak 6 orang $(37,5 \%)$. Sedangkan ibu dengan paritas rendah yang mengalami anemia sebanyak 3 orang $(13,6 \%)$ dan 19 orang $(86,4 \%)$ tidak mengalami anemia. Berdasarkan hasil uji chi-square memperoleh $p$ value $=0,005<\alpha=0,05$, dapat disimpulkan bahwa ada hubungan antara paritas ibu dengan kejadian anemia.

Hasil penelitian ini sejalan dengan hasil penelitian yang dilakukan oleh Serli pada tahun 2010 di Palembang dengan jumlah sampel 150 responden, dengan kelompok tingkat paritas tinggi yang anemia yaitu 28 orang $(50,9 \%)$, dan yang tidak anemia yaitu 27 orang (49,1\%). Sedangkan pada kelompok tingkat paritas rendah dengan anemia sebesar 21 orang $(22,1 \%)$ dan yang tidak anemia yaitu 74 orang $(77,9 \%)$, dengan $p$ value $=0,000<\alpha=0,05$.

Paritas adalah jumlah anak yang telah dilahirkan oleh seorang ibu baik lahir hidup maupun lahir mati. Seorang ibu yang sering melahirkan mempunyai resiko mengalami anemia pada kehamilan berikutnya apabila tidak memperhatikan kebutuhan nutrisi. Karena selama hamil zat-zat gizi akan terbagi untuk ibu dan untuk janin yang dikandungnya.[8]

Berdasarkan hasil penelitian, teori, serta hasil penelitian terkait maka peneliti berpendapat bahwa paritas ibu hamil yang mempunyai anak $>3$ sangat mempengaruhi terjadinya anemia dalam kehamilan dibandingkan dengan ibu yang mempunyai anak $\leq 3$. Karena pada kehamilan yang berulang dapat menimbulkan kerusakan pada pembuluh darah dan dinding uterus yang biasanya mempengaruhi sirkulasi nutrisi ke janin, sehingga semakin tinggi paritas ibu maka semakin tinggi pula resiko terkena anemia.

\section{c. Hubungan Antara Pengetahuan Ibu dengan Kejadian Anemia di Puskesmas Makrayu Palembang}

Berdasarkan hasil analisis univariat dari 38 responden diketahui bahwa 23 responden (60,5\%) mempunyai pengetahuan yang kurang baik, dan 15 orang (39,5\%) pengetahuannya baik. Sedangkan dari hasil analisis bivariat responden yang mempunyai pengetahuan kurang baik dan anemia sebanyak 12 responden $(52,2 \%)$, dan yang tidak mengalami anemia sebanyak 11 orang (47,8\%). Sedangkan responden dengan pengetahuan baik dan menderita anemia sebanyak 1 orang $(6,7 \%)$, dan yang tidak anemia sebanyak 14 orang (93,3\%). Berdasarkan hasil uji chisquare memperoleh $\mathrm{P}$ value $=0,011<\alpha=0,05$, dapat disimpulkan bahwa ada hubungan antara pengetahuan ibu dengan kejadian anemia.

Hasil penelitian ini sejalan dengan penelitian yang dilakukan oleh Yuliana pada tahun 2009 di semarang dengan jumlah sampel 42 responden, Hasil penelitian menunjukkan dari 27 responden yang mengalami anemia sebanyak 8 orang $(29,6 \%)$ memiliki tingkat pengetahuan tentang anemia dalam kategori baik dan 19 orang $(70,4 \%)$ memiliki tingkat pengetahuan tentang anemia dalam kategori kurang. Dari 15 orang responden yang tidak mengalami anemia sebanyak 13 orang $(86,7 \%)$ memiliki pengetahuan tentang anemia dalam kategori baik dan 2 orang (13,3\%) memiliki tingkat pengetahuan tentang anemia dalam kategori kurang. Dan didapatkan nilai $\mathrm{p}$ value yaitu sebesar $0,000<0,05(\mathrm{p}<\alpha)$.

Berdasarkan hasil penelitian, teori serta hasil penelitian terkait maka peneliti berpendapat bahwa pengetahuan ibu hamil yang kurang baik, sangat mempengaruhi kejadian anemia dalam kehamilan, karena pengetahuan ibu yang kurang baik mempunyai pengaruh terhadap perilaku kesehatan khususnya pada saat seorang wanita hamil, kurang optimalnya perilaku kesehatan ibu hamil untuk mencegah terjadinya anemia. Misalnya, kurangnya konsumsi makanan yang mengandung zat besi selama kehamilan yang dikarenakan oleh ketidaktahuannya.

\section{SIMPULAN DAN SARAN}

\section{Simpulan}

Berdasarkan data yang diperoleh dari hasil penelitian yang sudah dilakukan di Puskesmas Makrayu Palembang tahun 2019, peneliti menarik beberapa kesimpulan sebagai berikut:

a. Ditribusi frekuensi ibu hamil yang anemia sebanyak 13 orang $(34,2 \%)$ dan yang tidak anemia sebanyak 25 orang $(65,8 \%)$

b. Distribusi frekuensi ibu hamil yang umurnya resiko , yaitu sebanyak 21 orang $(55,3 \%)$ dan yang tidak risiko yaitu 17 orang $(44,7 \%)$ 
c. Distribusi frekuensi ibu hamil dengan paritas tinggi yaitu 16 orang $(42,1 \%)$ dan 22 orang $(57,9 \%)$ dengan paritas rendah.

d. Distribusi frekuensi ibu hamil dengan pengatahuan kurang baik yaitu sebanyak 23 orang $(60,5 \%)$ dan yang pengetahuannya baik 15 orang $(39,5 \%)$

e. Ada hubungan yang bermakna antara umur dengan kejadian anemia pada ibu hamil, dimana $\rho$ value $=$ 0,023

f. Ada hubungan yang bermakna antara paritas dengan kejadian anemia pada ibu hamil, dimana $\rho$ value $=0,005$

g. Ada hubungan yang bermakna antara pengetahuan dengan kejadian anemia pada ibu hamil, dimana $\rho$ value $=0,011$

\section{Saran}

Agar hasil penelitian ini dapat menjadi acuan dan menambah wawasan bagi peneliti, dan bagi peneliti selanjutnya agar melakukan penelitian dengan variabel - variabel lain yang dapat menghasilkan hasil yang lebih akurat.

\section{DAFTAR RUJUKAN}

[1] Asrinah, Asuhan Kebidanan Masa Kehamilan. 2017.

[2] World Health Organization, "The global prevalence of anaemia in 2011," WHO, 2015.

[3] SDKI, "Laporan Pendahuluan Survey Demografi dan Kesehatan Indonesia 2017," in Survey Demografi dan Kesehatan Indonesia 2017, 2017.

[4] B. P. Statistika, "Angka Kematian Bayi," Sumber : Sensus Penduduk 1971, 1980, 1990, SDKI 1994 dan 1997, 2015.

[5] G. Stephen, M. Mgongo, T. Hussein Hashim, J. Katanga, B. Stray-Pedersen, and S. E. Msuya, "Anaemia in Pregnancy: Prevalence, Risk Factors, and Adverse Perinatal Outcomes in Northern Tanzania," Anemia, 2018.

[6] D. Astuti and U. Kulsum, "Pola Makan dan Umur Kehamilan Trimester III dengan Anemia pada Ibu Hamil," Indonesia. J. Kebidanan, 2018.

[7] E. P. Kusparlina, "Hubungan antara Umur dan Status Gizi Ibu Berdasarkan Ukuran Lingkar Lengan Atas dengan Jenis BBLR Eny," J. Penelit. Kesehat. Suara Forikes, 2016.

[8] Rangga Satria Pamungkas, D. S. Argadireja, and R. K. Sakinah, "Hubungan Usia Ibu dan Paritas dengan Tingkat Kejadian BBLR di Wilayah Kerja Puskesmas Plered, Kecamatan Plered Kabupaten Purwakarta Tahun 2014," Pros. Pendidik. Dr., 2015.

[9] Dinas Kesehatan Kota Palembang. 2012. Profil Dinkes Kota Palembang: Dinas Kesehatan Kota Palembang.

[10] Puskesmas Makrayu Palembang. 2013. Profil Puskesmas Makrayu Palembang. Puskesmas Makrayu Palembang. 